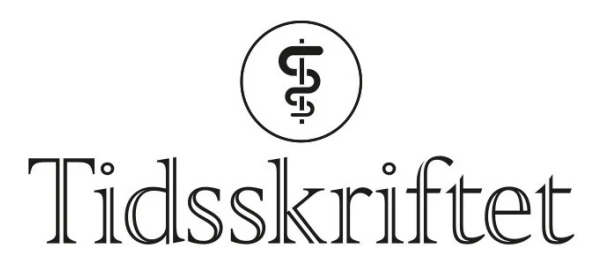

DEN NORSKE LEGEFORENING

\title{
Helsedata - Sammenstilt statistikk fra flere registre
}

KOMMENTAR

INGER JOHANNE LANDSJØÅSEN BAKKEN

inger.johanne.bakken@helsedir.no

Inger Johanne Landsjøåsen Bakken er seniorrådgiver.

EVEN GUNNARSON ANDERSSEN

KNUT IVAR JOHANSEN

Ingen av forfatterne har oppgitt noen interessekonflikter.

I et debattinnlegg i Tidsskriftet nr. 14/2021 beskriver Solli og Halkinrud (11) hvordan data fra flere helseregistre kan benyttes som kilde til statistikk. Som eksempel presenterer forfatterne hvordan de fikk tilgang til statistikk over komorbiditet blant kvinner med brystkreft. Utvalget ble definert i data fra Kreftregisteret (kvinner med brystkreft) mens data fra Reseptregisteret ble benyttet for komorbiditet. Forfatterne fikk utlevert ferdig statistikk (anonyme opplysninger).

Forfatterne har rett i at dette er en metodikk som er lite benyttet, og vi i avdeling helseregistre i Helsedirektoratet er enige i at metoden kunne vært brukt mer. Metoden reduserer behovet for utlevering av personidentifiserbare helsedata, noe som er bra for personvernet. Helseregisterloven åpner for at opplysninger fra ulike helseregistre kan sammenstilles for utarbeidelse og tilgjengeliggjøring av statistikk, dersom statistikken skal brukes innenfor de aktuelle registrenes formål. Behandling av statistikk er ikke regulert av personvernlovgivningen og det skal derfor være enklere å få tilgang til statistikk enn til personidentifiserbare helsedata. Kapasiteten i de aktuelle registermiljøene vil imidlertid, på samme måte som for annen datatilgang, være avgjørende for hvor raskt statistikk kan tilgjengeliggjøres.

Vi mener at data fra Kommunalt pasient- og brukerregister (KPR) og Norsk pasientregister (NPR) ville vært et mer nærliggende valg som kilde til informasjon om komorbiditet $\mathrm{i}$ eksempelet til Solli og Halkinrud. Disse registrene dekker til sammen hele den offentlige helsetjenesten i Norge. Registrene forvaltes av Helsedirektoratet, og omfatter informasjon om tilstander pasientene har vært behandlet for (2). 
Avdeling helseregistre kobler rutinemessig data fra KPR og NPR og har også tilgang til Folkeregisteret. Hauge og medarbeidere har publisert en artikkel om komorbiditet blant barn innlagt for influensa i perioden 2017 - 2019 basert på sammensatt statistikk (3). I dette tilfellet ble populasjonen (barn innlagt for influensa) definert i Norsk pasientregister (NPR) mens informasjon om komorbiditet ble basert på data fra både Norsk pasientregister (NPR) og Kommunalt pasient- og brukerregister (KPR).

Metodikken er den samme om data fra flere registre skal kobles. Fødselsnummer krypteres på forskjellige måter i de ulike registrene og alle koblingsprosesser starter med å tilrettelegge nøkkelfiler slik at hver person i utvalget får samme løpenummer uavhengig av datakilde.

Som eksempel på kobling med flere datakilder ble det i pandemiens første fase tilrettelagt statistikk basert på data fra Norsk pasientregister, Kommunalt pasient- og brukerregister, Folkeregisteret og Meldesystem for smittsomme sykdommer. Arbeidet resulterte blant annet i tre artikler publisert i Tidsskriftet $(\underline{4}, \mathbf{5}, \underline{6})$.

Vi oppfordrer til å vurdere bruk av statistiske data fra helseregistrene til forskning og analyse. Det er positivt at det blir spredt kunnskap om muligheten til å fremstille statistikk basert på data fra flere registre. Vi håper at etableringen av Helsedataservice kan bidra til $ø$ kt bruk av denne muligheten.

\section{LITTERATUR}

1. Solli O, Halkinrud M. Helsedata - en enkel metode for utvidet innsikt. Tidsskr Nor Legeforen 2021; 141. doi: 10.4045/tidsskr.21.0633. [PubMed][CrossRef]

2. Bakken IJ, Ariansen AMS, Knudsen GP et al. The Norwegian Patient Registry and the Norwegian Registry for Primary Health Care: Research potential of two nationwide health-care registries. Scand J Public Health 2020; 48: 49-55. [PubMed][CrossRef]

3. Hauge SH, Bakken IJ, de Blasio BF et al. Correction to: Risk conditions in children hospitalized with influenza in Norway, 2017-2019. BMC Infect Dis 2021; 21: 197. [PubMed][CrossRef]

4. Størdal K, Bakken IJ, Greve-Isdahl M et al. Sars-CoV-2 hos barn og ungdom i Norge: påvist smitte, sykehusinnleggelser og underliggende tilstander. Tidsskr Nor Legeforen 2020; 140. doi: 10.4045/tidsskr.20.0457. [PubMed][CrossRef]

5. Nystad W, Hjellvik V, Larsen IK et al. Underliggende tilstander hos voksne med covid-19. Tidsskr Nor Legeforen 2020; 140. doi: 10.4045/tidsskr.20.0512. [PubMed][CrossRef]

6. Gulseth HL, Helland E, Johansen KI et al. Dødsfall etter påvist SARS-CoV-2 i Norge. Tidsskr Nor Legeforen 2020; 140. doi: 10.4045/tidsskr.20.0693. [PubMed][CrossRef]

Publisert: 22. november 2021. Tidsskr Nor Legeforen. DOI: 10.4045/tidsskr.21.0768

(C) Tidsskrift for Den norske legeforening 2023. Lastet ned fra tidsskriftet.no 26. april 2023. 